\title{
The consumer's motivation towards online purchase intention of chicken meat during the Covid-19 pandemic
}

\author{
Silvia Dewi Sagita Andik*, Arief Daryanto, and Pria Sembada \\ College of Vocational Studies, IPB University
}

\begin{abstract}
The extent of the Corona virus or Covid-19 in various countries, including in Indonesia, has impacted numerous sectors. The Covid-19 pandemic will have potentially caused changes to the normal food system for chicken meat commodities in Indonesia. Among them is a shift in consumer behaviour in getting access to chicken meat. Consumers' online purchase intention is seen as an appropriate alternative during the pandemic, especially for consumers in the red zones. This study was conducted to analyse factors that impact online purchase intention on Chicken meat during the pandemic. This research uses data survey of 316 consumers in Jakarta, Bogor, Depok (Red zone areas). The analysis used is SEM using AMOS software. The results show that there are situation impact and hedonic influence towards online purchase intention of the chicken meat during the pandemic. We provide recommendation for companies on how to address consumers purchase motives.
\end{abstract}

\section{Introduction}

The COVID-19 pandemic has brought numerous changes in almost all businesses worldwide. One of them is the change in the livestock industry purchasing system, e.g., the chicken meat. Usually, most consumers would buy chicken meat directly from traditional markets. However, the limited access due to the COVID-19 pandemic has forced business to shift to the online system and is followed by consumers. The enhancement of transactions through online applications indicates a shift in consumer behaviour towards food and beverage purchasing [1]. The shifting in the sales system from offline to online systems urges consumers to adapt as well. Many factors have affected online food purchasing during COVID 19 pandemic, and among them is the situational factor [2].

Situational factors are factors in a particular time and place during the observation which is not followed by personal attributes (intra-individual) or other stimuli. Indonesia is one of the countries affected by the COVID 19 worldwide pandemic. The Indonesian government issued a regulation called Large-Scale Social Restrictions (PSBB), which limited any social activities. This situation has caused many public places to be restricted or even closed, such as malls, markets, supermarkets, and entertainment venues. Consequently, many businesses shifted their marketing means to the online system. During the COVID-19 pandemic, online

* Corresponding author: silviadewi@apps.ipb.ac.id 
marketing positively impacts social distancing practices [3]. Situational factors also influence online purchasing during the COVID-19 pandemic [4,5]. A lot of items, such as hijabs and books, are sold through online applications $[4,6]$. However, only a few previous research investigates the grocery product purchasing situation through online application during the COVID-19 pandemic, in term of chicken meat products.

Concerning the situation factors, the influence of consumer psychology also plays a role in the online purchasing system during the COVID 19 pandemic. Consumer psychology covers consumer characteristics and motivations. Motivation is defined as the driving force within an individual that compels them to do an action [7]. In relation to consumer motivation in purchasing intention, there are two dimensions of motivations observed in previous research, i.e., hedonic motivation and utilitarian motivation $[4,8,9]$.

Utilitarian motivation represents people who have the intention to shop because of the necessity factor. In contrast, Hedonic motivation relates to the shopping desire of a person to get pleasure [10]. Hedonic motivation drives consumers to shop through online application or websites in term of luxury products. In addition, consumers are likely to get attracted to images and promotions on websites or online applications. Hedonic motivation typically has the dominant role in increasing consumer interest in online purchasing; however, only a few studies observe hedonic motivation in purchasing food, especially during the COVID-19 pandemic. Limited access forces sellers to close their shops, resulting in businesses selling their goods through online applications, including food \& meat products. This condition makes consumers have many alternative choices of goods sold through online. Moreover, many chicken meat sellers offer discount for consumer. In addition, utilitarian motivation also has impact on food online purchase intention. Generally, utilitarian motivation driver consumers to buy chicken meat online during the COVID 19 pandemic. Consumers will always meet their needs such as buying food during the COVID 19 pandemic even though there is limited access. This is interesting to observe as this study examines consumer's motivation and intention on purchasing chicken meat through online channels during the COVID-19 pandemic.

\section{Methods}

\subsection{Data Collection and procedure}

The study was conducted from August to October 2020. The data were collected using an online questionnaire to 316 respondents in JABODETABEK (Jakarta, Bogor, Depok, Tangerang, and Bekasi). Definition of red zone is area that have a high incidence of COVID 19 infection. The red zone in Indonesia covers Jakarta Bogor, Depok, Tangerang and Bekasi city. The total sample size is at least five times the number of indicators in the study. There are 12 indicators in this study, resulting in the minimum total sample of 60 . Thus, this study meet the population requirements which is more than 60 sample (316 sample).

The technique used for sampling in this study was non probability sampling. Purposive sampling was chosen because of the ease of access and willingness of the respondents to be interviewed. Sampling respondents were selected based on these specific criteria: (1) had purchased chicken meat online (2) the residence was in Jakarta Greater Area (Jabodetabek).

\subsection{Measure and analysis}

The variables in this study included independent variables, i.e., the situational factor, hedonic motivation, and utilitarian motivation and online purchase intention as the dependent variable. A Likert scale of 1 - 5 was used as the measurement scale in the questionnaire, and 
the data analysis applied descriptive and SEM analysis using AMOS software. Descriptive analysis was used to calculate respondent characteristics, while SEM - AMOS analysis was used to test the causality among variables. One of the advantages of SEM is able to examine complex causality relationships among variables [11].

\subsection{Hypotheses development}

The online purchase system is a priority of consumer alternative during the COVID-19 pandemic [4]. The limited access drives consumers adaptable to the current chaotic situation. One of the implications of the COVID 19 pandemic is the changing consumer behavior. Most of the sellers sold perishables or fashion products through online system. the COVID-19 pandemic has encouraged all businesses to sell food online, including chicken meat. Several factors driver consumers to make online purchasing, i.e., situational factors and also consumer motivation factors $[4,10]$. Previous research examined the influence of situational factors on online purchase intentions for book products during the COVID 19 pandemic [4]. In addition to situational factors, consumer motivation is also considered to have an important role in online purchase intentions.

Consumer motivation covers hedonic motivation and utilitarian motivation. Hedonic motivation affects consumers to purchases online due to hedonic motivation create a feeling of comfort and enjoyment when seeing products in online application. Meanwhile, utilitarian motivation encourages consumers to make online purchases to meet their needs [12].

H1: Situational Factor (PS) affects online purchase intention of chicken meat during the COVID-19 pandemic

H2: Hedonic motivation $(\mathrm{MH})$ affects online purchase intention of chicken meat during the COVID-19 pandemic

H3: Utilitarian motivation (MU) affects online purchase intention of chicken meat during the COVID-19 pandemic

\section{Results and discussion}

\subsection{Respondent characteristics}

The respondent characteristics cover gender, age, level of education and income. The demographic characteristics of the 316 respondents are presented in Table 1. It shows that respondents were primarily females (56\%) with an age range of 26 - 35 years old $(60 \%)$, indicating that most respondents are considered young. Young people spent their time browsing the internet, including online purchasing $[13,14]$. They are more aware of the adoption of technology innovation [15]. Based on the education level, the majority of respondents are a Diploma or bachelor's degree (53\%). Most of the respondents have income ranging from IDR 2,500,001 to 5,000,000 (35\%), following a previous study which states that socio-demographics influences food online purchasing [16]. Young, well-educated people and hold an adequate financial level would likely have online purchasing intention of chicken meat. Relate to the gender, the result show most of respondent are female. It indicates that the decision making to buy chicken meat through online is women. 
Table 1. Respondent Characteristics.

\begin{tabular}{|c|c|c|}
\hline \multicolumn{2}{|c|}{ Characteristics } & \multicolumn{2}{c|}{ Percentage } \\
\hline Gender & 179 & 56 \\
\hline Female & 137 & 44 \\
\hline Male & $\mathbf{3 1 6}$ & $\mathbf{1 0 0}$ \\
\hline Age & 118 & 37 \\
\hline $17-25$ & 189 & 60 \\
\hline $26-35$ & 8 & 2 \\
\hline $36-45$ & 1 & 1 \\
\hline$>45$ & $\mathbf{3 1 6}$ & $\mathbf{1 0 0}$ \\
\hline Total & 119 & 37 \\
\hline Level of Education & 171 & 53 \\
\hline High School & 26 & 10 \\
\hline Diploma/Bachelor's Degree & $\mathbf{3 1 6}$ & $\mathbf{1 0 0}$ \\
\hline Undergraduate & 39 & 12 \\
\hline Total & 66 & 21 \\
\hline Income (IDR) & 112 & 35 \\
\hline$<1.000 .000$ & 64 & 20 \\
\hline $1.000 .000-2.500 .000$ & 35 & 12 \\
\hline $2.500 .001-5.000 .000$ & $\mathbf{3 1 6}$ & $\mathbf{1 0 0}$ \\
\hline $5.000 .001-10.000 .000$ & &
\end{tabular}

\subsection{Reliability and construct validity}

There are several criteria in SEM analysis. One of them are the reliability and validity test. The standard value of reliability (CR) is above 0.70, while the standard value of Average Variance Extract (AVE) is above 0.50. Based on the reliability (CR) and Average Variance Extract (AVE) calculation, several parameters would then be removed since they do not meet the standard values of CR and AVE. After that, the model will be re-calculated, resulting in the following values as follows:

Table 2. Instrument Test

\begin{tabular}{|l|c|c|}
\hline \multicolumn{1}{|c|}{ Variable } & CR & AVE \\
\hline Situational Factor & 0.753 & 0.511 \\
\hline Hedonic Motivation & 0.852 & 0.662 \\
\hline Utilitarian Motivation & 0.842 & 0.642 \\
\hline Online Purchase Intention & 0.928 & 0.813 \\
\hline
\end{tabular}

Table 2 shows the CR and AVE values. Four variables measure the reliability (CR) and average extract variance (AVE), i.e., situational factors, hedonic motivation, utilitarian motivation, and online purchase intention. All variables have met the standard values, specifically CRs are above 0.70 and AVEs are above 0.50 . Thus, the model developed does not have any validity and reliability issues. 


\subsection{Flow chart development}

The SEM causality model is developed based on literature studies where each variable is believed to have a relationship and an influence on other variables. Figure 1 shows the calculation results of the SEM AMOS analysis, and the model is viewed as suitable.

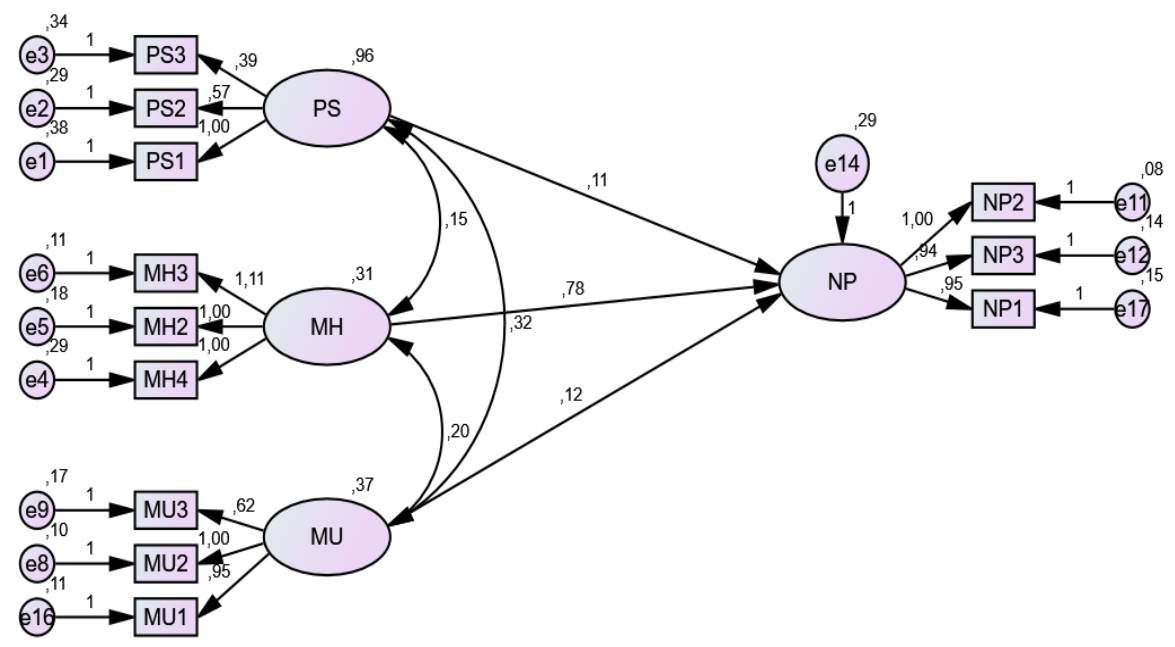

Note: $\mathbf{P S}=$ Situational Factor, $\mathbf{M H}=$ Hedonic Motivation, $\mathbf{M U}=$ Utilitarian Motivation, $\mathbf{N P}=$ Online Purchase Intention.

Fig. 1. Model Fit

\subsection{Model rating}

The feasibility of the model is evaluated through several Goodness-Of-Fit criteria. The first step is to evaluate the data used in this study whether it is in accordance with the SEM criteria or not, following the number of samples, normality, linearity, multi-collinearity, and similarity. Table 3 shows the results of model suitability based on several criteria.

Table 3. The Suitability of Model

\begin{tabular}{|c|c|c|c|}
\hline $\begin{array}{c}\text { Goodness of Fit } \\
\text { Indicators }\end{array}$ & Cutt-Off & Value & Result \\
\hline P-value & $>0.05$ & 0.00 & Not Fit \\
\hline Df & Small & 48 & Not Fit \\
\hline GFI & $>0.90$ & 0.937 & Fit \\
\hline RMR & $<0.05$ & 0.029 & Fit \\
\hline AGFI & $>0.90$ & 0.897 & Not Fit \\
\hline RMSEA & $<0.08$ & 0.072 & Fit \\
\hline NPI & $>0.9$ & 0.945 & Fit \\
\hline RFI & $>0.9$ & 0.924 & Fit \\
\hline IFI & $>0.9$ & 0.965 & Fit \\
\hline CMIN / DF & $<2.00$ & 2.645 & Not Fit \\
\hline TLI & $>0.95$ & 0.951 & Fit \\
\hline CFI & $>0.95$ & 0.964 & Fit \\
\hline
\end{tabular}

Based on GOF (Goodness of Fit) results, 8 out of 12 criteria have met the requirements (fit). Therefore, since more than $50 \%$ of the criteria meet the requirements, the model is 
considered suitable. Consequently, it suggests that the data follows the model developed, and the overall model used is categorized as good.

\subsection{Hypothesis testing}

This study tested three hypotheses, and all carried out using Structural Equation Modelling (SEM) analysis. Hypothesis testing is conducted to see the strength of the latent factor dimensions, which can be noticed from the value of the weighted regression model. The value of the Critical Ratio is larger than 2.0, indicating that those variables are the dimensions of the latent factors formed.

Table 4. Result of structural equation model

\begin{tabular}{|c|c|c|c|c|c|}
\hline & Estimate & S.E. & C.R. & P & Hypothesis \\
\hline NP $\leftarrow$ PS & .109 & .050 & 2.177 & .029 & H1 Accepted \\
\hline NP $\leftarrow$ MH & .782 & .100 & 7.837 & $* * *$ & H2 Accepted \\
\hline NP $\leftarrow$ MU & .119 & .097 & 1.230 & .219 & H3 Not Accepted \\
\hline
\end{tabular}

Based on Table 4, there are two out of the three hypotheses that have significant influence. The first hypothesis with a p-value $<0.05$ states that Situational Factor (PS) significantly influences the chicken meat online purchase intention. The value of $\mathrm{C}$. $\mathrm{R}$ situational factor (2.177) is above 2.0, and the value of p-value (0.029) is below 0.05 , indicating $\mathrm{H} 1$ as accepted and confirming that Situational Factor influences the online purchasing intention of Chicken Meat during COVID 19 pandemic.

This finding reveals that situational factor influences chicken meat online purchase intention during the COVID 19 pandemic. Most consumers would likely purchase chicken meat through online channels due to limited access to the market, health issues, and government regulations to reduce activity in the public area. For example, in Indonesia, there is a Large-Scale Social Restriction (PSBB) regulation. This regulation has led to many shops switching from offline to online, including food stores. Therefore, online shopping activity is undoubtedly among many trends that arise during the COVID-19 pandemic [17,18]. This finding is aligned with [16], which states that situational factors such as COVID-19 pandemic influences online food purchasing. In addition, this finding is in line with previous research that states COVID 19 situational has an impact on consumer intention to purchase books online [4].

On the second hypothesis, the value of C. R Hedonic motivation (7.837) is also above 2.0, with a p-value (0.000) is less than 0.01 , confirming that $\mathrm{H} 2$, Hedonic Motivation influences the chicken meat online purchasing intention, is accepted. This finding is also aligned with the research conducted by [19]. She argues that hedonic has a positive and significant attitude toward online purchase intention, whereas attitude is an intervening variable. Consumers tend to buy chicken meat online when there is an appealing thing, such as a promotional campaign, discount, and engaging advertising on the website. Hedonic motivation is related to consumer experience when they visit the website. Consumers are more attracted to engaging pictures on website or e-commerce platforms. In addition, recent research stressed that promotion might also attract price-sensitive consumers, causing them to choose the channel which provides them with the best value for money [20].

The value of $\mathrm{C}$. $\mathrm{R}$ of utilitarian motivation in the third hypothesis (1.230) is less than 2.0, and the value of p-value (0.219) is above 0.05 , resulting in $\mathrm{H} 3$ not accepted. Utilitarian motivation is not proven to drive consumers to buy chicken meat online during the COVID19 pandemic. This research has the same finding as the previous research. Hedonic motivation is a better predictor of purchase intentions than utilitarian motives for online shopping [21]. 
The results of the study show that the influence of the COVID-19 pandemic situation increase the consumers intention to buy chicken meat online. Business actors should take advantage of the opportunities that exist during the covid 19 pandemic. Business actors can sell chicken meat directly to consumers (Business to Consumer). According to government regulations related to limited access (PSBB), business actors are expected to facilitate consumers to get chicken meat easily through online applications. In addition, hedonic motivation also influences consumers intention to buy chicken meat online. Then business actors must create a marketplace that attracts consumers' attention, such as attractive photos of fresh chicken meat and discount promos. Business actors also provide delivery services to make it easier for consumers.

\section{Conclusion}

The COVID-19 pandemic has multiple impacts in many sectors, including the business sector, causing many businesses to switch to online ways of doing their business from previously offline. This finding shows changes in consumer behaviour, as consumers are now more likely to purchase things online, especially for their daily needs, such as chicken meat. This phenomenon is one of the captivating things that businesses must take into account, as they are required to change their marketing strategy. This study also reveals that the influence of the situation factor and hedonic motivation indeed lead consumers in purchasing chicken meat online.

The COVID-19 pandemic situation requires consumers to purchase chicken meat online to avoid physical contacts with other people to reduce the risk of being contracted with the COVID-19 virus. In addition, the motivation for purchasing chicken meat online is the comfortable and enjoyable feeling when seeing fresh chicken meat through online applications. This study also revealed that utilitarian motivation does not significantly affect online purchase intention of chicken meat during the COVID-19 pandemic.

Acknowledgement. The authors gratefully acknowledge College of Vocational School (IPB University), who funded this study. We are also thankful to the farmers and the poultry industries and its distributors, suppliers and consumers for their cooperation during the study

\section{References}

1. S. Irawan, R. Octaviani, R.Suminar, Advances in Transportations and Logistics Research. (2020)

2. A. Youssef, J. Asmaa, M.Belhcen, Lhacen, Factors Affecting the Online Purchase Intention during COVID-19 Crisis: The Case of Morocco. Available at SSRN: https://ssrn.com/abstract=3734389

3. Awali, F. Rohmah, Balanca: Jurnal Ekonomi Dan Bisnis Islam, 2 (2020)

4. N. Nguyen, H.X. Tran, L.V. Huy, X.N. Nguyen, M.T Do, Publishing Research Quarterly, 36 (2020)

5. S. Ali, N. Khalid, H.M.U. Javed, D.M.Z. Islam, Journal of Open Innovation: Technology, Market, and Complexity. 7, 1 (2021)

6. Sumarliah, S.U. Khan, I.U. Khan, Journal of Islamic Marketing, 12, 3 (2021)

7. Schiffman, L. Kanuk, Costumer Behavior, Internasional Edition, (Prentice Hall, 2000)

8. Mikalef, M. Giannakos, A. Pateli. Exploring the Business Potential of social media: A Utilitarian and Hedonic Motivation Approach. 25th Bled Conference Dependability: Reliable and Trustworthy Structures, Processes, Operations and Services for the Future, (2012) 
9. S. Novela, Y. O. Sihombing, Novita, E. Caroline, R. Octavia, Proceedings of the 2020 International Conference on Information Management and Technology (ICIMTech), (2020)

10. P. R. Cardoso, S. C. Pinto, Int. J. Retail Distrib. Manag., (2010)

11. U.S.A. Hair, F. Joseph, Multivariate Data Analysis 7th Edition. Pearson. (Education Limited. Harlow. England, 2010)

12. Sütütemiz, M. Saygıll. The Retail and Marketing Review, 16, 1 (2020)

13. Y.S. Lim, A. Omar, R. Thurasamy, International Journal of Business and Management, 10, 6 (2015)

14. Mudaa, R. Mohdb, S. Hassan, Procedia Economics and Finance, 37 (2016)

15. Kotler, G. Armstrong. Principles of Marketing, (Prentice-Hall, Eaglewood Cliffs, NJ., 2010)

16. Dominici, F. Boncinelli, F. Gerini, E. Marone, Journal of Retailing and Consumer Services, 60 (2021)

17. Bhatti, H. Akram, H.M. Basit, A.U. Khan, S.M.R. Naqvi, M. Bilal, International Journal of Future Generation Communication and Networking. 13, 2 (2020)

18. Akar, Journal of Internet Commerce, (2021)

19. S. N. Rasyida, Iqtishodia: Jurnal Ekonomi Syariah, 6, 1 (2021)

20. V.C.S. Yeo, S.K. Goh, S. Rezaei, Journal of Retailing and Consumer Services, 35 (2017)

21. Koch, B. Frommeyer, G. Schewe. Sustainability. 12, 24 (2020) 